\title{
Acupuncture Used as a Method of Peripheral Nerve Stimulation in Chronic Prostatitis: A Case Study
}

Hervik J* and Stub T

Vestfold Hospital Trust, The Arctic University of Norway,

National Research Centre for Complementary and

Alternative Medicine, Norway

*Corresponding author: Jill Hervik, Vestfold Hospital Trust, Norway

Received: J uly 08, 2021; Accepted: August 03, 2021;

Published: August 10, 2021

\section{Introduction}

Chronic Prostatitis/Chronic Pelvic Pain Syndrome (CP/CPPS) is defined as chronic pelvic pain lasting for at least 3 months, often associated with lower urinary tract symptoms and/or sexual dysfunction [1]. Prostatitis is a common condition, with $35-50 \%$ of men affected by symptoms suggesting prostatitis during their lifetime. It is associated with negative psychological effects and substantial health care costs [2]. There are currently many approaches for its management, using both pharmacological and non-pharmacological interventions, though there is a lack of evidence for the efficacy of these treatments.

A systematic review [3] examined the evidence for 16 different pharmacological treatments of CP/CPPS. Ninety-nine studies included 9119 men. Treatment approaches included alpha-blockers, 5-alpha reductase inhibitors, antibiotics, anti-inflammatories, allopurinol and botulinum toxin injections. The authors found low- to very low-quality evidence that these interventions cause a reduction in prostatitis symptoms, without an increased incidence of adverse events in the short term. They reported lack of evidence regarding the effects of these drugs on sexual dysfunction, quality of life, or anxiety and depression.

The efficacy of acupuncture on CP/CPPS was examined in a systematic review and meta-analysis [4] of 10 published trials $(\mathrm{n}=770)$. Analysis revealed that acupuncture significantly reduced the National Institute of Health-Chronic Prostatitis Symptom Index (NIH-CPSI) score and provided pain relief, compared to standard medication, and reduced symptoms when compared to sham. Four acupuncture sessions were the minimum "dose" to reach clinical efficacy, and prolonged acupuncture sessions continuously improved urinary symptoms and quality of life.

Peripheral Nerve Stimulation (PNS) is an effective tool for the treatment of chronic pain. Miniaturized devices that are less invasive than previous generations has brought this treatment modality into mainstream use. Recent clinical evidence suggests clinically significant and sustained reductions in pain can persist well beyond the PNS treatment period [5].

Acupuncture is a minimally invasive method of PNS. Acupuncture points have been shown to overlie major neuronal bundles, which correlate with cutaneous branches of major nerves [6]. These nerves converge and interact with visceral nociceptive inputs at the spinal cord level. This anatomical correlation provides the basis on which acupuncture applied to a specific region could treat a variety of conditions such as prostatitis, remote to the site of treatment.

\section{Case Presentation}

The patient was a 64-year-old previously healthy, non-smoking, male psychologist. He was not taking any medication. During September 2020, an irritating, itchy rash developed on the head of his penis, after 2 weeks it spread to the shaft. He was advised to use anti-fungal cream (Canesten $10 \mathrm{mg} / \mathrm{g}$ ) twice a day by his General Practitioner (GP). The rash was not reduced after 4 weeks of use. A referral to a dermatologist resulted in a prescription for hydrocortisone cream $(10 \mathrm{mg} / \mathrm{g})$, which reduced itching for 30-60 minutes after application but was otherwise ineffective.

The patients' symptoms increased in November. As well as the rash, he was troubled by an ache in his testicles and perineum. $\mathrm{He}$ also experienced sexual dysfunction, lack of erection during sexual activity, and the cessation of nightly spontaneous erection. $\mathrm{He}$ experienced an increased frequency of urination at night and the flow was interrupted.

In January 2021 the patient was referred to a consultant urologist, who found normal prostate-specific antigen levels. After a clinical examination, he was diagnosed with bacterial prostatitis. He was prescribed trimethoprim $160 \mathrm{mg}$-sulfamethoxazole $800 \mathrm{mg}$ ( 1 tablet twice a day), voltaren (75 mg twice a day) and tamsulosin ( $0.4 \mathrm{mg}$ once a day) for 4 weeks. During the first 3 weeks the penile rash and the peroneal/testicular ache were reduced, but his symptoms increased again during the fourth week of medication use. After a second and later a third consultation, different antibiotics, doxycycline $(100 \mathrm{mg}$ twice a day) and ciprofloxacin (500mg twice a day), were successively prescribed, each of them for 4 weeks, with continued use of voltaren and tamsulosin. The patient again experienced initial symptom relief, but a return of symptom severity during the fourth week. Adverse effects during the second and third periods included extreme tiredness, lack of energy, weight loss $(4 \mathrm{~kg})$ and diarrhea when medicated with ciprofloxacin. Between the three separate monthly periods when antibiotics were prescribed, the patient had a 7 day wash out period without antibiotics, but he continued to take voltaren and tamulosin. Symptoms increased during these weeks to the same level recorded before the start of each antibiotic treatment.

The patient did not take any time off work. However, from late January 2021 until the end of May he suffered from a progressively increasing lack of energy during work hours and reported an increase in the need for sleep ( 2 hours after work and going to bed at night an hour earlier than usual). 


\begin{tabular}{|c|c|c|c|c|}
\hline Date & Symptoms before treatment start & Treatment & Result after 4 weeks of treatment & Adverse effects \\
\hline Sep 2020 & $\begin{array}{l}\text { Rash-head of penis } \\
\text { CPSI score: } 13\end{array}$ & $\begin{array}{l}\text { Canesten }(10 \mathrm{mg} / \mathrm{g}) \text { applied } 3 \text { times } \\
\text { a day for } 1 \text { month. }\end{array}$ & $\begin{array}{l}\text { No effect } \\
\text { CPSI score: } 15\end{array}$ & None \\
\hline Oct 2020 & $\begin{array}{l}\text { Rash - head and distal penis shaft } \\
\text { CPSI score: } 15\end{array}$ & $\begin{array}{l}\text { Hydrocortisone cream }(10 \mathrm{mg} / \mathrm{g}) \\
\text { applied } 3 \text { times a day for } 1 \mathrm{month} \text {. }\end{array}$ & $\begin{array}{l}\text { No effect } \\
\text { CPSI score: } 18\end{array}$ & $\begin{array}{l}\text { Reduced penis } \\
\text { skin elasticity }\end{array}$ \\
\hline $\begin{array}{l}\text { November/ } \\
\text { Dec } 2020\end{array}$ & $\begin{array}{l}\text { Penile rash. Ache in perineum and testicles. } \\
\text { Interrupted urinary flow. Increased urination } \\
\text { frequency at night. } \\
\text { Sexual dysfunction. } \\
\text { CPSI score: } 26\end{array}$ & $\begin{array}{l}\text { Paracetamol 500mg x2 } \\
\text { Hydrocortisone cream }(10 \mathrm{~g} / \mathrm{g}) \\
\text { applied } 3 \text { times a day for } 1 \text { month }\end{array}$ & $\begin{array}{l}\text { Short term pain relief ( } 2 \text { hours) } \\
\text { CPSI score: } 26\end{array}$ & $\begin{array}{l}\text { Reduced penis } \\
\text { skin elasticity }\end{array}$ \\
\hline Jan 2021 & $\begin{array}{l}\text { Same symptoms } \\
\text { CPSI score: } 26\end{array}$ & $\begin{array}{l}\text { Trimethoprim }-160 \mathrm{mg} \\
\text { sulfamethoxazole }-800 \mathrm{mg} \times 2 \\
\text { Voltaren } 75 \mathrm{mg} \times 2 \text { Tamsulosin } \\
0.4 \mathrm{mg} \times 1 \\
\text { Treatment duration } 4 \text { weeks }\end{array}$ & $\begin{array}{l}\text { Reduction of all symptoms, during the first } 3 \\
\text { weeks (CPSI: 11) increase in symptoms during } \\
\text { the fourth week of treatment. } \\
\text { CPSI score: } 21\end{array}$ & $\begin{array}{l}\text { Whole body rash } \\
\text { Some tiredness/ } \\
\text { lack of energy from } \\
\text { week } 4\end{array}$ \\
\hline Mar 2021 & $\begin{array}{l}\text { Same symptoms } \\
\text { CPSI score: } 26\end{array}$ & $\begin{array}{l}\text { Ciproflaxacin } 500 \mathrm{mg} \times 2 \text { Tamsulosin } \\
0.4 \mathrm{mg} \times 1 \\
\text { Voltaren } 75 \mathrm{mg} \times 2 \\
\text { Treatment duration } 4 \text { weeks }\end{array}$ & $\begin{array}{l}\text { Same result as previous period } \\
\text { CPSI score: } 25\end{array}$ & $\begin{array}{l}\text { Increasing } \\
\text { tiredness and lack } \\
\text { of energy } \\
\text { Weight loss }\end{array}$ \\
\hline May 2021 & $\begin{array}{l}\text { Same symptoms } \\
\text { CPSI score: } 28\end{array}$ & $\begin{array}{l}\text { Doxycycline } 500 \mathrm{mg} \times 2 \text { Tamsulosin } \\
0.4 \mathrm{mg} \times 1 \text { Voltaren } 75 \mathrm{mg} \times 2 \\
\text { Treatment duration } 4 \text { weeks }\end{array}$ & $\begin{array}{l}\text { Same result as previous period } \\
\text { CPSI score: } 26\end{array}$ & $\begin{array}{l}\text { Tiredness. Lack of } \\
\text { energy } \\
\text { Diarrhea }\end{array}$ \\
\hline Jun 2021 & $\begin{array}{l}\text { Same symptoms } \\
\text { CPSI score: } 26\end{array}$ & $\begin{array}{l}\text { Electro-acupuncture } \\
\text { Paracetamol } 500 \mathrm{mg} \times 1 \text { when } \\
\text { needed } \\
\text { Treatment duration } 4 \text { weeks }\end{array}$ & $\begin{array}{l}\text { Initial exacerbation of rash and peroneal ache } \\
\text { (1-4 treatments) } \\
\text { Reduction in perineal/testicular ache and } \\
\text { strong reduction in symptoms of tiredness after } \\
4^{\text {th }} \text { treatment. } \\
\text { After } 6^{\text {th }} \text { treatment normal sexual function, } \\
\text { return of spontaneous erection at night. } \\
\text { Reduced frequency of urination at night. } \\
\text { Urinary flow still interrupted. } \\
\text { Slight rash on the penis head } \\
\text { Average frequency of paracetamol use was } 1 x \\
500 m g \text { twice a week. } \\
\text { CPSI score: } 11\end{array}$ & None \\
\hline
\end{tabular}

From June 2021 he stopped all medication apart from Paracetamol $500 \mathrm{x} 1$ before bed when needed, and was treated with electroacupuncture every second day for a total of 4 weeks (14 treatments).

Treatment results were monitored by information noted by the patient once a week in a symptom diary and by the use of the validated National Institute of Health-Chronic Prostatitis Symptom Index. The total index score was recorded before and after each new type of treatment.

\section{Time-Line for Case History}

\section{Acupuncture therapy}

Treatment was not based on traditional Chinese medicine principles (Table 1). The area to be treated was chosen to correspond with the segmental innervation of the prostate (T12-S4). Needles were inserted into the fascia over the lower thoracic, lumbar and sacral vertebrae. Needles were angled distally and stimulated by hand, until pain radiated distally from the needle tip. Another needle was inserted where the radiating pain stopped, and so on. This so-called relay method is often used in peripheral neuralgia conditions, and was chosen as an appropriate method in this case in order to ensure that the strong needle stimulation covered all relevant segments.

Electrical stimulation with alternating high $(100 \mathrm{~Hz})$ and low $(2 \mathrm{~Hz})$ frequencies was applied to all needles to ensure maximum stimulation of the brain, as well as the spinal cord. The main inhibiting pain pathways include ARC-PAG- NRM (arcuate nucleus, periaqueduct grey and nucleus raphe magnus), it responds to lower frequencies; whilst the PBN (parabrachial nucleus)-PAG-NRM pathway reacts to higher frequencies. The use of alternating frequencies ensures the excretion of the broadest range of neuropeptides. Low frequencies affect $\mu$ - og $\delta$-opioid receptors and the excretion of $\beta$-endorphin, encephalin and endomorphin. Whereas higher frequencies produce analgesia by affecting the $\kappa$-opioid receptor, which results in excretion of dynorphin [7].

On a segmental level, muscle ergo-receptors send connections to spinal cord segmentally stimulating sympathetic response. Reduced sympathetic tone in skin, muscles and internal organs on segmental levels, when treatment exceeds 20 minutes [8].

Fourteen treatments were administered, at 2-day intervals, treatment sessions lasted 30 minutes. 


\section{Strengths and limitations}

This case study documents responses to various treatments, ending with 6 weeks of acupuncture. A strength of this study is that it documents variations in symptoms during treatments. The effects of which were subjectively noted in a diary, and objectively scored using the NIH-CPSI system. Another strength is the documentation of adverse effects.

A possible limitation of this study is that the reduction of symptoms during the electro-acupuncture phase might have been spontaneous. On the other hand, the improvement during acupuncture appeared to have an increasing cumulative effect as treatments progressed. Another limitation is that monitoring of symptoms stopped after the last treatment, there was no follow up. So, whether the electroacupuncture treatments had any long-term effect, is not known.

This case study provides information of value in the planning of clinical trials with long-term follow up and provides increased treatment options in a clinical setting.

\section{Results}

Chronic prostatitis is a condition without any evidence-based treatment alternatives. Results of each treatment in this case study did not just produce a start and end of treatment result, variation of symptoms was also reported during treatments. Specifically all three antibiotics initially stimulated symptom relief, but after $75 \%$ of the treatment time had elapsed, symptoms returned. The opposite effect was reported where electro-acupuncture was concerned; an initial worsening of symptoms was followed by a reduction. Because needles have been used as a means of stimulation we call the needling intervention acupuncture, it is however just a simple way of delivering peripheral nerve stimulation.

Adverse effects were connected to the use of all three types of antibiotics. Progressively increasing tiredness became a significant problem, during ciproflaxacin and doxycycline use. Also during the use of the third type of antibiotic, the patient had bouts of diarrhea. We consider tiredness and diarrhea to be adverse effects, symptoms that considerably reduced the patients' quality of life. These adverse effects may have been connected to the specific drug used, or to the cumulative effect and total length of antibiotic use. Diarrhea is listed as a possible adverse effect of tamsulosin, this alpha blocker was taken continuously throughout all three antibiotic phases. No adverse effects were observed during treatment with acupuncture.

\section{Conclusion}

Electro-acupuncture used as a method of peripheral nerve stimulation appears to be an effective treatment for chronic prostatitis. A condition that needs more attention from a clinical perspective. Further long-term studies are warranted, investigating acupuncture as an individual and combined therapy.

\section{References}

1. Krieger JN, Nyberg L, Nickel JC. NIH consensus definition and classification of prostatitis. JAMA. 1999; 282: 236-237.

2. Krieger JN, Nyberg L, Nickel JC. NIH consensus definition and classification of prostatitis. JAMA. 1999; 282: 236-237. [Krieger JN, Lee SW, Jeon J, Cheah PY, Liong ML, Riley DE. Epidemiology of prostatitis. Int J Antimicrob Agents. 2008; 31: S85-S90]

3. Franco JVA, Turk $\mathrm{T}$, Jung JH, Xiao Y-T, lakhno S, Tirapegui FI, et al. Pharmacological interventions for treating chronic prostatitis/chronic pelvic pain syndrome: a Cochrane systematic review. BJU Int. 2020; 125: 490-496.

4. Zhang $W$, Fang $Y$, Shi M, Zhang M, Chen Y, Zhou T. Optimal acupoint and session of acupuncture for patients with chronic prostatitis/chronic pelvic pain syndrome: a meta-analysis. Transl Androl Urol. 2021; 10: 143-153.

5. Deer TR, Esposito MF, McRoberts MP, Grider JS. A Systematic Literature Review of Peripheral Nerve Stimulation Therapies for the Treatment of Pain. Pain Med. 2020; 21: 1590-1603.

6. Zhou W, Benharash P. Effects and mechanisms of acupuncture based on the principle of meridians. J Acupunct Meridian Stud. 2014 ; 7: 190-193.

7. Han JS. Acupuncture: neuropeptide release produced by electrical stimulation of different frequencies. Neuroscience 2003; 26: 17-22.

8. Shen J. Research on the neurophysiological mechanisms of acupuncture: review of selected studies and methodological issues. J Altern Complement Med. 2001; 7: 121-127. 